selected by doctors who are not directly involved in the transplantation effort. Their opinion as to the accept. ability of the donor should be based on crucial and irreversible bodily damage and imminent death. The prospective recipient should also be examined by an independent group of doctors, including a cardiologist and an immunologist. Their decision should be based on all the evidence, including the presence of advanced, irreversible cardiac damage and the likelihood of benefit from the procedure.

\section{School Leavers}

VoldMe 2 of Statistics of Education-one of at least five volumes covering different educational subjectshas been published this week by HMSO (price 20s.). This particular volume deals with General Certificate of Education examinations, Certificate of Secondary Education examinations, and school leavers.

From the numerous lists of figures, a rising trend in the number of students qualifiod in GCE can be seen. In fact, during the ten years ending in 1966, the number of passes at O-level almost doubled. The biggest increases were in economics (and associated subjects) 490 per cent-and in the other social science and vocational subjects group-200 per cent. Naturally enough, the greatest number of entrants were in English and mathematics, with geography and French not far behind. Physics also seems to have been popular, with an average of 54.7 per cent passes. Successes in the A-level examinations showed an increase of nearly 150 per cent during the last decade and the only decrease was in botany which fell by 9 per cent. English literature and physics were the two most popular subjects. The total of 140,000 CSE candidates for 1966 was more than twice the number for 1965 , with entries for boys averaging $4 \cdot 3$ subjects each and for girls $3 \cdot 2$ subjects each.

In $1965-66,38.5$ per cent of all leavers attempted 0 -level, and of these 21 per cent obtained five or more passes. Of over 15 per cent who attempted Alevel, 11 per cent obtained two or more passes. The data also show that 16.5 per cent of leavers went on to further education: $7 \cdot 5$ per cent each to universities and to other full-time further education, and 1.5 per cent to colleges of further education.

Regional statisties show that the proportion of all leavers going to full-time further education was above the national average in Wales and in the south of England except Greater London, and that the number leaving with two or more A-levels was highest in south-east and south-west England. A similar trend was shown for those leaving with five or more A-levels, with a percentage of 24.7 per cent for Wales closely following the figures of 26.8 and 26.4 for the southeast and south-west respectively.

\section{Committee on Education}

The British Parliament has now proceeded with the plan to set up a specialist committee of the House of Commons to deal with educational topics. The membership of the committee, announced last week, includes ten Labour members, seven Conservatives and no others, a source of some frustration to the dozen Liberals in the House of Commons. As well as being large, the select committee is also eminent. It includes a former Conservative Minister of Education, Sir Edward Boyle, and a former Labour Minister, Mr Fred Willey, who was Minister of Land and Natural Resources until that ministry disappeared. Before that he was for many years a Labour spokesman on education. The Labour Party, with almost as many teachers in the House of Commons as the Conservatives have lawyers, ran the risk of turning the committee into little more than a teachers' lobby. This seems to have been resisted, although several of the members are former teachers-Mr Christopher Price, Mr Trevor Park and Mr Richard Mitchell have all taught at schools, and Mr Stanley Henig is a former university lecturer. Among the Conservatives there are no former teachers, except Mr Richard Hornby, who taught for two years at Eton. There is, however, $\mathrm{Mr}$ Esmond Wright, who until his election as member for Glasgow Pollock was professor of modern history at the University of Glasgow.

The final terms of reference of the committee are a compromise. In its original form, the motion establishing the committee put down by Mr Richard Crossman, Leader of the House of Commons, did not mention Scotland, and the committee had no Scottish members. This was later changed, and the committee is now empowered to examine the activities of the Scottish Education Department as well as the Department of Education and Science. It now has two Scottish members. But this has not satisfied members from Scotland, who are hard to satisfy. They say, quite truthfully, that Scotland has an entirely separate system of education, and deserves a committee to itself-a committee empowered to examine the work of the Scottish Office as a whole.

Mr Crossman has made it quite clear that the committee is not a committee on education. Rather, it is a committee charged to examine the activities of the Department of Education and Science and the Scottish Education Department-it is a departmental rather than a subject committee. Mr Crossman already scems halfway to admitting that it was a mistake to establish the committee on this basis. "It is arguable that subject committees are, on the whole, better and easier to work. . . . It may be in the final resort that we come only to subject committees; but we were pledged to try out a departmental committee." There is now a select committee on agriculture and one on education, both organized on departmental lines. This has been done, it is thought, because Mr Anthony Crosland and Mr Fred Peart were the two ministers initially most enthusiastic about specialist committees. Mr Crosland has now moved on to the Board of Trade, leaving $\mathrm{Mr}$ Patrick Gordon Walker, still having an unhappy time as a minister, to handle the select committee as best he can. Mr Peart, still Minister of Agriculture, is probably finding the committee on agriculture more of a problem than he bargained for.

The committee will be meeting in public, and its chairman will be Mr Fred Willey. As its first subject, it has chosen to examine the Inspectorate of Schools. This is the body which certifies the standards of all schools in Britain, and is likely to prove a tepid subject politically. The committee has clearly decided to play itself in gently, and is likely to start the examination by summoning civil servants rather than ministers from the Department of Education and Science. 